\title{
Estimation of in situ rates of heterotrophy using diurnal changes in dissolved organic matter and growth rates of picoplankton in diffusion culture
}

\author{
J. McN. Sieburth, K. M. Johnson, C. M. Burney \& D. M. Lavore \\ Graduate School of Oceanography, University of Rhode Island; \\ Kingston, Rhode Island, USA
}

\begin{abstract}
A scheme has been developed for observing diurnal changes in dissolved organic matter in the photic zone and correlating them with specific microbial fractions and their rates of growth and uptake. Particulate ATP for procaryote and protist size fractions were augmented by pigment analyses to differentiate phototroph from phagotroph dominated accumulations. A temporary daytime increase in carbohydrates of some $32 \%$ above pre-dawn threshold values accounted for $41 \%$ of the labile DOC. Polysaccharide and monosaccharide maxima were mainly associated with phagotrophic protists, the monosaccharide maxima occurring during the daytime. Apparent maximum in situ heterotrophic uptake rates of this released DOC of $9.8 \mu \mathrm{g} \mathrm{C} \mathrm{L}^{-1} \mathrm{hr}^{-1}$ agree well with the growth rates of natural populations of the bacterial size fraction (picoplankton) on in situ water in diffusion culture of $5.1 \mu \mathrm{g} \mathrm{C} \mathrm{L}^{-1}$ $\mathrm{hr}^{-1}$. This growth was associated with phototroph maxima but occurred only during the afternoon and evening hours and not during the early morning and intense daylight hours. Proposed follow-up studies are outlined.
\end{abstract}

\section{INTRODUCTION}

In the photic zone of the sea, the microbial plankton consisting of phototrophic protists (microalgae), phagotrophic protists (protozoa), and osmotrophic procaryotes (bacteria) occurs in sufficient density that even in the open sea, a 10 or $100 \mathrm{ml}$ portion of water will yield reproducible assays for particulate ATP analyses. The study of the trophodynamics of this dominant fraction of the plankton has largely ignored its role in the release and uptake of the labile components of the dissolved organic matter (DOM). This is due to the assumption that the DOM in the sea is of great complexity and stability, the lack of sensitive and reliable methods to analyze for labile constituents, and the lack of an adequate technique for observing the effect of natural DOM fluxes on the growth of natural populations of bacterioplankton. However, evidence has accumulated that indicates that DOM could be a central factor in the trophodynamics of microbial plankton. We know that some $25 \%$ of the photosynthesate is leaked by the phototrophs during their metabolism (Antia et al., 1963; Horne et al., 1969; Anderson \& Zeutschel, 1970; Sorokin, 1971). From the available 
literature one might surmise that during the ingestion and digestion of the phototrophs another $25 \%$ is digested by the phagotrophs, $25 \%$ is leaked back to the sea as DOC, while the remaining $25 \%$ consisting of structural materials is defecated to become suspended organic debris. If this assumed division approaches reality, then for every part of particulate organic carbon (POC) passed up the food chain, about two parts of DOC are made available to the bacterioplankton. Assuming a 50\% efficiency of conversion to bacterial protoplasm, then as much bacterial carbon can theoretically pass up the food chain as does phototrophic carbon.

Strickland (1971) knew that DOC and bacterioplankton were important factors in the trophodynamics of the microbial plankton. However, there was no data available to him on the populations of bacterioplankton, their rates of growth in situ and the dynamic state of the DOC. He had to work within the confines of the rates of primary production and heterotrophic potential obtained with ${ }^{14} \mathrm{C}$ assays in isolated water samples. Such values for the open sea do not tally with the abundance of higher trophic forms (Steele, 1974; Mills, 1975). Predation by protozoa and the dwindling supply of nutrients in isolated samples must be yielding values that underestimate in-situ activities. During the past five years our laboratory has been developing methods and procedures that will estimate in-situ concentrations and changes and provide an alternative to ${ }^{14} \mathrm{C}$ bottle experiments. These include methods for determining two carbohydrate fractions that account for a significant portion of the labile DOC, methods for determining the distribution of microbial plankton, and methods for determining the growth rates of natural populations of "picoplankton" or "bacterioplankton" on in-situ DOC. Although we are publishing these procedures and results from the open ocean in greater detail in refereed journals, we cannot miss this opportunity to present a summary of our work to date before this auspicious gathering of individuals interested in ecosystems and their trophodynamics.

\section{METHODOLOGY}

Areas sampled from R/V TRIDENT during cruise TR-170 were along the outer continental shelf between Rhode Island and Newfoundland and across the Atlantic via the Azores to Spain during July and August 1975, and consisted of 15 hydrocasts with four 30-hour diurnal drift stations. The locations were determined by satellite navigator and the water profile through the photic zone was characterized with an XBT for temperature, quantum sensor for light attenuation, and a Turner fluorometer for plant pigments. All water samples for water chemistry and the determination of microbial plankton fractions were obtained in Niskin bottles scrubbed with $\mathrm{N} / 10 \mathrm{HCl}$ and rinsed at depth for 20 minutes. The 51 samples from a number of depths spanning the oxygen, phototroph and phagotroph maxima were used to determine DOC by the method of Menzel \& Vaccaro (1964), total carbohydrates and polysaccharides (Burney \& Sieburth, 1977), and monosaccharides (Johnson \& Sieburth, 1977), as well as the particulate ATP (Holm-Hansen \& Booth, 1966; Hamilton \& Holm-Hansen, 1967; Allen, 1972; Cheer et al., 1974) in the procaryote (picoplankton) $(0.2$ to $3 \mu \mathrm{m})$ and protist ( 3 to $1000 \mu \mathrm{m}$ ) fractions, and plant pigments (Holm- 
Hansen et al., 1965). Suspended particles greater than $3 \mu \mathrm{m}$ were concentrated to useful densities of 500 to 1000 x by passing 2001 volumes obtained with 301 Niskin bottles through a continuous reverse flow concentrator (Hinga \& Sieburth, in preparation) and then used for serial decimal dilutions for culture or prepared for light and electron microscopy. The less than $3 \mu \mathrm{m}$ fraction served as an inoculum of picoplankton (Sieburth \& Lavoie, in press) dominated by heterotrophic bacteria whose growth on natural fluxes of DOC was observed in diffusion culture chambers (Lavoie $\&$ Sieburth in prep.).

\section{DISCUSSION AND PRESENTATION OF SELECTED RESULTS}

A scientific party of 12 working flat-out were required to make the necessary observations during TR-170. The scheme used for profiling, sampling, analysis and culture during the hydrocasts and diurnal pumping stations is shown in Figure 1. The cruise leader called stations and rigidly monitored the progress of profiling, sampling, analysis and preliminary data plotting while the marine technician (J. Hannon) aided

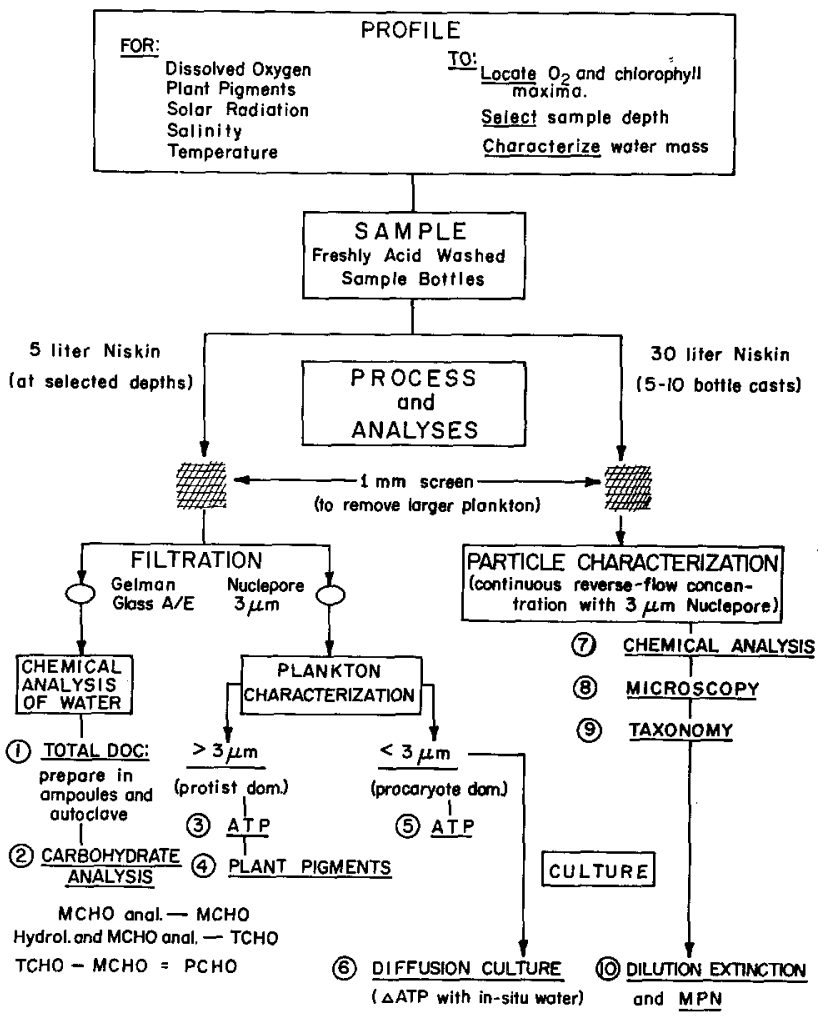

Fig. 1: Procedure used to characterize the dissolved organic matter and microbial plankton in a water mass and to estimate diurnal changes due to heterotrophy 
with the profiling and sampling and provided the standard hydrographic data. All hands helped with profiling and sampling from TRIDENT. P. Willis and F. French obtained neuston samples from a Zodiac inflatable and made and prepared the plankton tows from both vessels. French also made pigment analyses on filtrates from

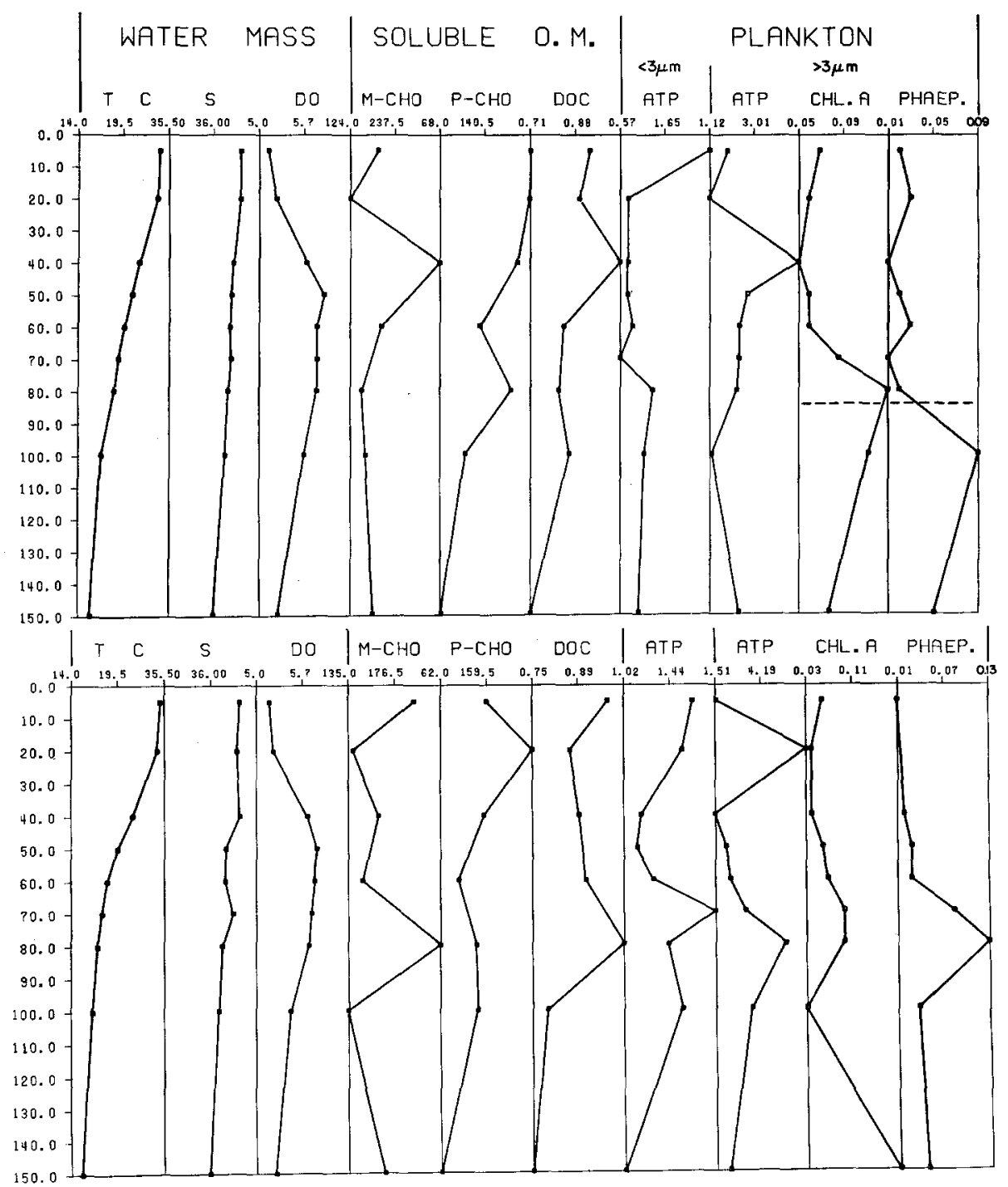

Fig. 2: A comparison of the daytime (upper) and predawn (lower) concentrations of the soluble organic matter and microbial plankton for a discrete water mass on the Azores Plateau (hydrocasts 11 and 12). Salinity (S) $\% / 0$, dissolved oxygen (DO) $\mathrm{ml} \mathrm{l}^{-1}$, total monosaccharide (M-CHO) and total polysaccharide (P-CHO) $\mu \mathrm{g} \mathrm{l} \mathrm{l}^{-1}$, dissolved organic carbon (DOC) $\mathrm{mg}^{-1}$, particulate ATP (ATP) fg ml $1^{-1} \times 10^{4}$, chlorophyll $a$ and phaeopigments $\mu \mathrm{g}^{-1}$. Dotted line indicates compensation depth 
the water samples. The dissolved organic matter was analysed by $\mathrm{K}$. Johnson and C. Burney with aid from S. Sieburth and B. McBurney. The plankton fractions and diffusion cultures were prepared and analysed by $\mathrm{D}$. Lavoie with help from $\mathrm{K}$. Hinga and P. Willis. The reverse flow concentrates were prepared, examined and cultured by P. Davis and D. Caron. The purpose of profiling was to locate the oxygen and chlorophyll maxima, select the sample depths and to characterize the water mass. The acid-scrubbed samplers apparently obtained samples with no detectable surface contamination, as noted by Sorokin (1971), and appears to be a practical alternative to sterile sampling. The oxygen, plant pigment, carbohydrate and ATP determinations from one hydrocast or station were completed before conducting the next and were plotted and used to help select the depths and sampling procedures for the next hydrocast. The DOC's and preparations for electron microscopy were analyzed ashore while the cultural observations lagged two weeks behind the sampling. Phase-contrast light microscopy of the reverse-flow concentrates and cultures was conducted aboard ship with appropriate head rests (Rogick, 1965).

An example of the type of information that was obtained is shown in Figure 2 which characterizes the water properties, soluble organic matter and microbial plankton for a discrete water mass on the Azores Plateau during both daylight and predawn the following day. The two hydrocasts taken a mile apart have very similar hydrographic properties (temperature, salinity and dissolved oxygen). The peaks in DOC are mirrored by peaks in the carbohydrate fractions. The monosaccharides during daylight hours were associated with a peak in protist ATP $(>3 \mu \mathrm{m})$ very low in plant pigments which indicates a phagotrophic population. This peak disappeared during the evening hours while a new monosaccharide peak present during the pre-dawn hour was associated with a peak in protist ATP coinciding with one for phaeopigments. The night time maximum for the polysaccharides coincided with a peak for phagotrophic protists. Values for the procaryotic ATP $(0.2$ to $3.0 \mu \mathrm{m})$ were always high in the shallowest sample while subsurface peaks were associated with maxima in plant pigments. The results for the surface microlayer are quite distinct and are presented elsewhere (Sieburth et al., 1976).

In order to develop a system for estimating the in situ growth rates for natural populations of bacteria on their natural substrates as they are released to the environment, a radical departure from the ${ }^{14} \mathrm{C}$ method for estimating heterotrophic potential in isolated water samples was indicated. The picoplankton fraction in a natural water sample serves as inoculum. Based upon the principles of dialysis culture laid down by Schultz \& Gerhardt (1969), Lavoie \& Sieburth (in prep.) have developed a diffusion culture chamber which has a sufficiently short $50 \%$ equilibrium time to monitor changes in the picoplankton as they occur but not too short as to produce a carrying capacity much greater than that of the natural water body. This chamber is shown in Figure $3 a$. The important feature is the provision of adequate agitation on both sides of the membrane to provide active diffusion and discourage fouling. Changes in the natural picoplankton inoculum are followed by ATP assays. When a constant nutrient supply is provided such as filter-sterilized seawater, the curve in Figure $3 \mathrm{~b}$ is obtained, where the carrying capacity is reached in $36 \mathrm{~h}$ followed by minor population fluctuations presumably due to interspecies competition. In contrast to this are the results obtained 


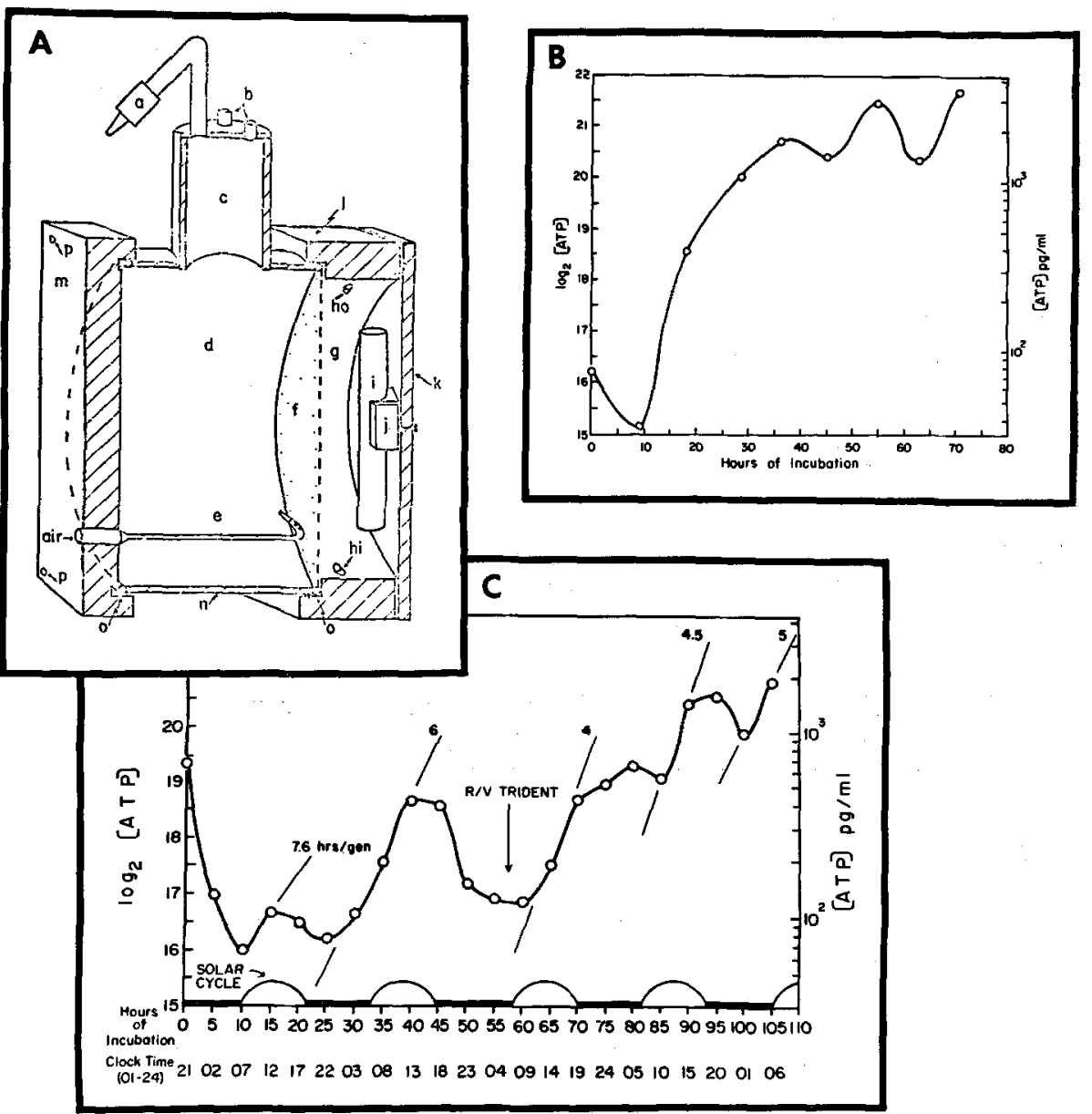

Fig. 3: Diffusion culture chamber and representative growth patterns of natural populations of picoplankton. A Cutaway view of $180 \mathrm{ml}$ polycarbonate cell showing $0.1 \mu \mathrm{m}$ Nuclepore filter (f), aerator tube (e) and mixing bar (i) for membrane agitation and one-way valve (a) for air exhaust; $B$ Growth curve on homogeneous batch of unenriched, filter-sterilized seawater; note maximum carrying capacity of system reached after $36 \mathrm{~h}$; $C$ Diurnal growth patterns on in-situ water at a dock and its perturbation by unexpected docking of research vessel. (Data from Lavoie \& Sieburth, in press)

with in situ water shown in Figure $3 c$ where growth is controlled by the nutrients released by the activities of the biota in the water mass. There is a daily period of growth associated, but out of phase, with diel periodicity, occurring during the afternoon and early evening hours. The unexpected docking of R/V TRIDENT during the experiment resuspended sediment, releasing nutrients which caused a temporary perturbation of the growth pattern.

Similar growth patterns for natural populations of picoplankton nurtured on water obtained from the depths of oxygen and chlorophyll maxima were obtained at 
Table 1

Estimated growth rates of picoplankton at the oxygen and chlorophyll maxima of the pumping stations spanning hydrocasts 13,14 and 15 , TR-170

\begin{tabular}{|c|c|c|c|c|c|c|}
\hline \multirow[b]{2}{*}{ Depth and periods } & \multirow{2}{*}{$\begin{array}{c}0 / 0 \\
\text { increase }\end{array}$} & \multirow{2}{*}{\multicolumn{2}{|c|}{$\times \underset{\left(\mu \mathrm{g} / \mathrm{m}^{3}\right)}{\text { Initial }}=$}} & \multirow[b]{2}{*}{$\underset{\left(\mu \mathrm{g} / \mathrm{m}^{3}\right)}{\mathrm{ATP}}$} & \multicolumn{2}{|c|}{ Increase } \\
\hline & & & & & $\begin{array}{l}\mu \mathrm{g} \text { cell } \\
(\mathrm{C} / \mathrm{l})\end{array}$ & $\begin{array}{l}\mu \mathrm{g} \text { cell } \\
(\mathrm{C} / \mathrm{l} / \mathrm{h})\end{array}$ \\
\hline \multicolumn{7}{|l|}{$50 \mathrm{~m} \mathrm{O}_{2}$ maximum } \\
\hline $\begin{array}{l}\text { 1st growth period } \\
18-22 \text { hrs }\end{array}$ & 123 & & 92 & 113 & 28.0 & 7.0 \\
\hline $\begin{array}{c}\text { 2nd growth period } \\
02-06 \mathrm{hrs} \\
06-10 \mathrm{hrs}\end{array}$ & $\begin{array}{l}37 \\
26\end{array}$ & & $\begin{array}{l}120 \\
150\end{array}$ & $\begin{array}{l}45 \\
39\end{array}$ & $\begin{array}{r}11.1 \\
9.7\end{array}$ & $\begin{array}{l}2.8 \\
2.4\end{array}$ \\
\hline \multicolumn{7}{|l|}{$\begin{array}{l}80 \mathrm{~m} \text { chlorophyll } \\
\text { maximum }\end{array}$} \\
\hline $\begin{array}{l}\text { 1st growth period } \\
14-18 \mathrm{hrs} \\
18-22 \mathrm{hrs}\end{array}$ & $\begin{array}{l}63 \\
43\end{array}$ & & $\begin{array}{r}89 \\
138\end{array}$ & $\begin{array}{l}55 \\
59\end{array}$ & $\begin{array}{l}13.7 \\
14.7\end{array}$ & $\begin{array}{l}3.4 \\
3.6\end{array}$ \\
\hline $\begin{array}{c}\text { 2nd growth period } \\
02-06 \mathrm{hrs} \\
06-10 \mathrm{hrs}\end{array}$ & $\begin{array}{l}42 \\
91\end{array}$ & & $\begin{array}{l}165 \\
220\end{array}$ & $\begin{array}{r}69 \\
200\end{array}$ & $\begin{array}{l}17.2 \\
50.0\end{array}$ & $\begin{array}{r}4.3 \\
12.5\end{array}$ \\
\hline Mean & 61 & & 139 & 83 & 20.6 & 5.1 \\
\hline
\end{tabular}

the station spanning hydrocasts 13 and 14 midway between the Azores and Spain, and the results are given in Table 1 . When growth occurred, rates obtained over four hour periods ranged from 2.4 to $12.5 \mu \mathrm{g}$ of cellular carbon $1^{-1} \mathrm{~h}^{-1}$ with a mean of $5.1 \mu \mathrm{g}$ of cell carbon $\mathrm{l}^{-1} \mathrm{~h}^{-1}$. A comparable value for Narragansett Bay, Rhode Island, was $8.4 \mu \mathrm{g}$ of cellular carbon $\mathrm{l}^{-1} \mathrm{~h}^{-1}$. The important question is whether this value, which is some two orders of magnitude above the glucose and glycolate uptake rates obtained with ${ }^{14} \mathrm{C}$ bottle assay procedures for similar water masses on

Table 2

Apparent maximum in situ heterotrophic uptake rates for dissolved organic matter in the North Atlantic

\begin{tabular}{|c|c|c|c|c|c|c|}
\hline \multirow[b]{2}{*}{$\begin{array}{l}\text { Hydro- } \\
\text { casts }\end{array}$} & \multirow[b]{2}{*}{ Location } & \multirow[b]{2}{*}{$\begin{array}{l}\text { Depth } \\
\text { (m) }\end{array}$} & \multicolumn{2}{|c|}{ Total CHO } & \multicolumn{2}{|c|}{ Total DOC } \\
\hline & & & $\begin{array}{c}\text { Uptake } \\
\mu \mathrm{g} \\
\mathrm{C} / 1\end{array}$ & $\begin{array}{c}\text { Rate } \\
\mu \mathrm{g} \\
\mathrm{C} / \mathrm{l} / \mathrm{h}\end{array}$ & $\begin{array}{l}\triangle \mathrm{TCHO} \\
\mathrm{C} / \triangle \mathrm{DOC}\end{array}$ & $\begin{array}{c}\text { Rate } \\
\mu \mathrm{g} \\
\mathrm{C} / 1 / \mathrm{h}\end{array}$ \\
\hline $5-6$ & $\begin{array}{l}43^{\circ} 31^{\prime} \text { N } 59^{\circ} 29^{\prime} \mathrm{W} \\
43^{\circ} 19^{\prime} \text { N } 59^{\circ} 41^{\prime} \mathrm{W}\end{array}$ & 20 & 64 & 4.1 & .27 & 15.2 \\
\hline $7-8$ & $\begin{array}{l}43^{\circ} 40^{\prime} \mathrm{N} 52^{\circ} 40^{\prime} \mathrm{W} \\
43^{\circ} 50^{\prime} \mathrm{N} 52^{\circ} 54^{\prime} \mathrm{W}\end{array}$ & 10 & 63 & 3.2 & .63 & 5.1 \\
\hline $11-12$ & $\begin{array}{l}37^{\circ} 28^{\prime} \mathrm{N} 28^{\circ} 43^{\prime} \mathrm{W} \\
37^{\circ} 28^{\prime} \mathrm{N} 28^{\circ} 44^{\prime} \mathrm{W}\end{array}$ & 40 & 93 & 5.3 & .58 & 9.1 \\
\hline $13-14$ & $\begin{array}{l}36^{\circ} 59^{\prime} \mathrm{N} 21^{\circ} 22^{\prime} \mathrm{W} \\
36^{\circ} 47^{\prime} \mathrm{N} 21^{\circ} 20^{\prime} \mathrm{W}\end{array}$ & 80 & 61 & 3.4 & - & - \\
\hline & Mean & & 70 & 4.0 & .49 & 9.8 \\
\hline
\end{tabular}


the same cruise (Yorgey, Wright \& Sieburth, unpublished data), is an artifact or a more valid estimate of in situ activities. If we take DOM values obtained at the diurnal stations and for the period of time between daylight maxima and pre-dawn minima, and calculate the apparent heterotrophic uptake rates, we get the maximum values shown in Table 2 . As we can see, the total carbohydrates can account for some $41 \%$ of the labile DOC and the mean uptake rates of the DOC were up to $9.8 \mu \mathrm{g}$ $\mathrm{C}^{-1} \mathrm{~h}^{-1}$. For bacteria to take up DOC at a rate of $9.8 \mu \mathrm{g} \mathrm{C}{ }^{-1} \mathrm{~h}^{-1}$ and convert it to cellular carbon at the rate of $5.1 \mu \mathrm{g} \mathrm{C}^{-1} \mathrm{~h}^{-1}$, a conversion efficiency of $52 \%$ would be required. Such a value appears reasonable. In Table 3 the apparent percentage of diurnally labile dissolved organic matter is calculated. The mean values of $13 \%$ for DOC and $32 \%$ for total carbohydrate indicates that DOC in the photic zone may

Table 3

Apparent maximum percentage of diurnally labile dissolved organic matter in the North Atlantic

\begin{tabular}{|cccccccc|}
\hline $\begin{array}{c}\text { Hydro- } \\
\text { cast }\end{array}$ & $\begin{array}{c}\text { Depth } \\
(\mathrm{m})\end{array}$ & $\begin{array}{c}\text { Day- } \mathrm{T}-\mathrm{CHO} / \mathrm{L} \\
\text { time }\end{array}$ & $\begin{array}{c}\text { Pre- } \\
\text { dawn }\end{array}$ & $\begin{array}{c}0 \% \\
\text { labile }\end{array}$ & $\begin{array}{c}\text { Day- } \\
\text { time }\end{array}$ & $\begin{array}{c}\text { Pre- } \\
\text { dawn }\end{array}$ & $\begin{array}{c}\% \\
\text { labile }\end{array}$ \\
\hline $5-6$ & 20 & 564 & 420 & 25 & 1.33 & 1.09 & 18 \\
$7-8$ & 10 & 583 & 432 & 26 & 1.25 & 1.15 & 8 \\
$11-12$ & 40 & 544 & 316 & 42 & 1.06 & 0.90 & 15 \\
$13-14$ & 80 & 408 & 262 & 36 & - & - & - \\
\hline Mean & & 525 & 358 & 32 & 1.21 & 1.05 & 13.4 \\
\hline
\end{tabular}

not be as stable as previously presumed. However, it must be remembered that both the apparent uptake rate of DOC and the apparent growth rates of the picoplankton are maximal values occurring over selected time periods from depths of intense microbial activity and are not to be extrapolated over the depth of the photic zone. Even so, similar but more detailed observations in a salt marsh gave rates only ten times those observed in the open sea.

\section{EPILOGUE}

It will take much more work to evaluate these procedures and to see if they indeed provide realistic estimates of the rates which occur in situ. The preliminary observations are encouraging. More detailed follow-up studies in Narragansett Bay and adjacent waters are verifying the marked diurnal pattern of microbial plankton activity and DOC release and uptake. The relationship of the DOM to the microbial plankton is now quite certain. By marking discrete water masses with a low profile buoy array which will also suspend the diffusion culture chambers, we hope to eliminate the contaminating influence of the Research Vessel and to remain within a particular water mass. After detailed daytime profiling to select the depths of chlorophyll and monomer maxima, bi-hourly observations over several diurnal cycles at these depths for changes in DOC and carbohydrate as well as the adenylate energy charge (Wiebe $\&$ Bancroft, 1975) of the plankton fractions should indicate the phys- 
iological state of the microbial plankton as well as the rates of release and uptake of total DOC and the monosaccharide and polysaccharide fractions.

In this way we hope to not only verify the rates of dissolved organic matter release and uptake but to determine why they occur. The revised procedures will be tested during the maiden cruise of our new research vessel, ENDEAVOR, in the Gulf of St. Lawrence and over Georges Bank in November, 1976. Proposed cruises along the outer continental shelf of the US in 1977, the Norwegian Coastal Stream in 1978, and along the Antarctic Peninsula in 1979 should provide a varied group of productive open waters in which to observe the rates of activity of microbial plankton and their influence on the rates of release and uptake of dissolved organic matter.

Acknowledgements. This work was made possible by NSF Grant DES-74-01537 A01 from the Biological Oceanography Program as well as NSF Grant OCE-64-00372 A05 which supported the operation of the late $R / V$ TRIDENT.

\section{LITERATURE CITED}

Allen, P. D., III. 1972. Development of the luminescence biometer for microbial detection. Devs ind. Microbiol. 14, 67-73.

Anderson, G. C. \& Zeutschel, R. P., 1970. Release of dissolved organic matter by marine phytoplankton in coastal and offshore areas of the northeast Pacific Ocean. Limnol. Oceanogr. 15, 402-407.

Antia, N. J., McAllister, C. D., Parsons, T. R., Stephens, K. \& Strickland, J. D. H., 1963. Further measurements of primary production using a large-volume plastic sphere. Limnol. Oceanogr. 8, 166-183.

Burney, C. M. \& Sieburth, J. McN., 1977. Dissolved carbohydrates in seawater. II. A spectrophotometric procedure for total carbohydrate analysis and polysaccharide estimation. Mar. Chem. 5, 15-28.

Cheer, S., Gentile, J. H. \& Hegre, C. S., 1974. Improved methods for ATP analysis. Analyt. Biochem. 60, 102-114.

Hamilton, R. D. \& Holm-Hansen, O., 1967. Adenosine triphosphate content of marine bacteria. Limnol. Oceanogr. 12, 319-324.

Hinga, K. R. \& Sieburth, J. McN. An improved method for reverse flow concentration of particles. (In prep.).

Holm-Hansen, O., Lorenzen, C. J., Holmes, R. W. \& Strickland, J. D. H., 1965. Fluorometric determination of chlorophyll. J. Cons, perm. int. Explor. Mer, 30, 3-15.

- \& Booth, C. R., 1966. The measurement of adenosine triphosphate in the ocean and its ecological significance. Limnol. Oceanogr. 11, 510-519.

Horne, A. J., Fogg, G. E. \& Eagle, D. J., 1969. Studies in situ of the primary production of an area of inshore Antarctic Sea. J. mar. biol. Ass. U. K. 49, 393-405.

Johnson, K. M. \& Sieburth, J. McN., 1977. Dissolved carbohydrates in seawater. I. A precise spectrophotometric analysis for monosaccharides. Mar. Chem. 5, 1-13.

Lavoie, D. M. \& Sieburth, J. McN. Culture of natural populations of heterotrophs from the picoplankton on diffusing nutrients from seawater. Appl. environm. Microbiol. (In press).

Menzel, D. W. \& Vaccaro, R. F., 1964. The measurement of dissolved organic and particulate carbon in seawater. Limnol. Oceanogr. 9, 138-142.

Mills, E. L., 1975. Benthic organisms and the structure of marine ecosystems. J. Fish. Res. Bd Can., 32, 1657-1663.

Rogick, M. D., 1965. Search for sargassum. Turtox News, 43 (8), 178-181.

Schultz, J. S. \& Gerhardt, P., 1969. Dialysis culture of microorganisms: Design, theory, and results. Bact. Rev., 33, 1-47. 
Sieburth, J. McN. \& Lavoie, D. M. Design of a standard method for estimating bacterioplankton biomass and production. Soviet-American J. mar. Pollut. (In press).

- Willis, P.-J., Johnson, K. M., Burney, C. M., Lavoie, D. M., Hinga, K. R., Caron, D. A., French, F. W., III, Johnson, P. W. \& Davis, P. G., 1976. Dissolved organic matter and heterotrophic microneuston in the surface microlayers of the North Atlantic. Science, N. Y. 194, 1415-1418.

Sorokin, Yu. I., 1971. On the role of bacteria in the productivity of tropical oceanic waters. Int. Revue ges. Hydrobiol., 56, 1-48.

Steele, J. H., 1974. The structure of marine ecosystems. Harvard University Press, Cambridge, Mass., 128 pp.

Strickland, J. D. H., 1971. Microbial activity in aquatic environments. Symp. Soc. gen. Microbiol. 21, 231-253.

Wiebe, W. J. \& Bancroft, K., 1975. Use of the adenylate energy charge ratio to measure growth state of natural microbial communities. Proc. natn. Acad. Sci. U.S.A. 72, 2112-2115.

First author's address: Dr. J. McN. Sieburth Graduate School of Oceanography University of Rhode Island Kingston, Rhode Island USA 